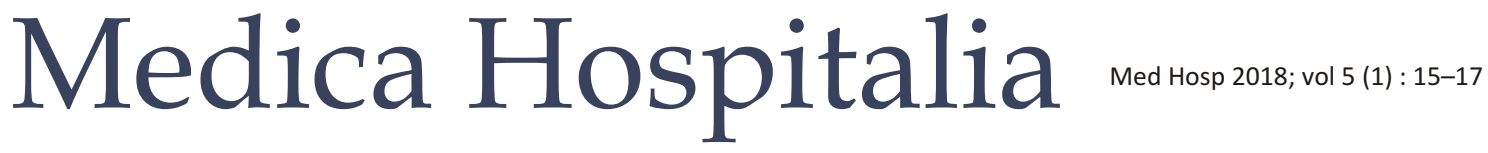

Original Article

\section{Hubungan Kadar TSH dan FT4 terhadap Koagulasi Darah yang Dinilai dengan PPT dan PTTK pada Pasien Hipertiroid}

\author{
Irenne $^{1}$, Lisyani Budipradigdo Suromo ${ }^{2}$ \\ ${ }^{1}$ Program Pendidikan Dokter Spesialis Patologi Klinik Fakultas Kedokteran UNDIP/RSUP Dr. Kariadi, Semarang \\ ${ }^{2}$ Bagian Patologi Klinik Fakultas Kedokteran Universitas Diponegoro, Semarang
}

\begin{abstract}
Abstrak
Latar belakang : Gangguan pada fungsi tiroid diketahui mempunyai pengaruh terhadap sistem koagulasi. Kondisi hipertiroid diamati mengalami peningkatan kadar von Willrbrand (vWF) dan fibrinogen. Penelitian mengenai hubungan thyroid stimulating hormone (TSH) dan free tetraiodothyronine (FT4) terhadap faktor koagulasi pada kondisi hipertiroid pernah diteliti tetapi terdapat perbedaan hasil dan terdapat kesenjangan antara teori dan praktik. Penelitian ini bertujuan untuk membuktikan hubungan TSH dan FT4 terhadap nilai plasma prothrombin time (PPT) dan partial thromboplastin time with kaolin (PTTK) pada pasien hipertiroid.

Metode : Empat puluh dua pasien hipertiroid yang memenuhi kriteria inklusi pada bulan Juni-Agustus 2016 di RSUP Dr. Kariadi Semarang. Desain penelitian analitik observasional dengan pendekatan belah lintang. TSH dan FT4 diukur menggunakan metode ELFA, PPT dan PTTK diukur menggunakan alat hematologi analyzer. Uji normalitas Saphiro-Wilk test dan uji korelasi TSH, FT4, PPT, dan PTTK menggunakan Spearman test.

Hasil : Analisis korelasi terdapat hubungan bermakna antara kadar TSH dan PPT $(p=0,023 ; r=0,35)$. Tidak terdapat hubungan bermakna antara kadar TSH dan FT4 $(p=0,908 ; r=-0,018)$, TSH dan PTTK $(p=0,165 ; r=0,218)$, FT4 dan PPT $(p=0,164 ; r=0,219)$, FT4 dan PTTK $(p=0,485 ; r=-0,111)$ pada pasien hipertiroid.

Simpulan : Terdapat hubungan positif lemah antara TSH dan PPT. Tidak terdapat hubungan yang bermakna antara TSH dan FT4, TSH dan PTTK, dan FT4 terhadap PPT dan PTTK. Dibutuhkan penelitian kohort pada pasien hipertiroid dengan terapi untuk membuktikan apakah hormon tiroid mempunyai hubungan dengan perubahan koagulasi.
\end{abstract}

Kata kunci : Hipertiroid, TSH, FT4, PPT, PTTK

\section{Correlation of TSH and FT4 level with coagulation test measured by PPT and PTTK value in hyperthyroid patients}

\begin{abstract}
Background : Thyroid disorder affects all coagulation system. Hyperthyroid known has increased of VWF and fibrinogen levels. Research on the relationshipthyroid stimulating hormone (TSH) and free tetraiodothyronine (FT4)against coagulation factors in hyperthyroid condition has been studied, but there are differences in the results and there is a gap between theory and practice. This study purpose to prove the correlation of TSH and FT4 with plasma prothrombin time (PPT) and partial thromboplastin time with kaolin (PTTK) value in hyperthyroid patients.

Methods : A total of fourty two hyperthyroid patient in June-August 2016 at Dr. Kariadi hospital, Semarang, that fulfilled the inclusion criteria. Study design with cross-sectional observational analysis. Level of TSH and FT4 were measured with ELFA method, PPT and PTTK were measured with hematology analyzer. Normality test with Saphiro-Wilk test dan correlation test for TSH, FT4, PPT, PTTK were measured with Spearman test.

Results : Correlation analysis have a significant correlation between TSH level and PPT value $(p=0.023 ; r=0.35)$. There are no significant correlation between TSH and FT4 level ( $p=0.908 ; r=-$ $0.018)$, TSH level and PTTK value ( $p=0.165 ; r=0.218)$, FT4 level and PPT value $(p=0.164 ; r=0.219)$, FT4 and PTTK value $(p=0.485 ; r=-$ 0.111 ) in hyperthyroid.

Conclusion : There is a positif weak correlation between TSH and PPT. There are no correlation between TSH and FT4 level, TSH level and PTTK value, FT4 level and PPT value, FT4 level and PTTK value. It takes a cohort of hyperthyroid patients with therapy to prove whether thyroid hormones have a relationship with changes in coagulation.
\end{abstract}

Keywords : Hyperthyroid, TSH, FT4, PPT, PTTK 


\section{PENDAHULUAN}

Hipertiroid adalah kondisi yang mengacu pada peningkatan hormon tiroid yang berlebihan, dapat ditimbulkan secara langsung dari peningkatan produksi kelenjar hormon tiroid. ${ }^{1,2}$ Berdasarkan riset kesehatan dasar 2013 ditemukan bahwa prevalensi penyakit hipertiroid di Indonesia diperkirakan sebesar 0,4\% dimana prevalensi pada perempuan cenderung lebih tinggi dibandingkan pada laki-laki. ${ }^{2}$

Gangguan pada fungsi tiroid diketahui mempunyai pengaruh terhadap sistem koagulasi. Kondisi hipertiroid diamati mengalami peningkatan kadar vWF dan fibrinogen. Umumnya kadar FT4 dihubungkan dengan perubahan parameter koagulasi namun belum diketahui apakah efek tersebut sebagian diantarai oleh $\mathrm{TSH}^{3}$ Penelitian Li Ll et al melaporkan bahwa pasien hipertiroid diketahui mengalami pemendekan PTTK dan mempunyai kadar fibrinogen lebih tinggi dibandingkan pada orang dengan fungsi tiroid normal. ${ }^{4}$ Penelitian mengenai hubungan TSH dan FT4 terhadap faktor koagulasi pada kondisi hipertiroid pernah diteliti tetapi terdapat perbedaan hasil dan terdapat kesenjangan antara teori dan praktik. Penelitian oleh Debeij et al melaporkan bahwa kadar TSH yang tinggi bukan penyebab utama peningkatan faktor koagulasi. $^{3}$ Sedangkan penelitian oleh Kilic et al menyatakan hiperkoagulasi dapat juga terjadi pada hipotiroid. ${ }^{5}$ Penelitian ini bertujuan untuk membuktikan hubungan TSH dan FT4 terhadap nilai PPT dan PTTK pada pasien hipertiroid.

\section{METODE}

Desain penelitian adalah analitik observasional dengan pendekatan belah lintang. Data diperoleh dari rekam medis pasien yang didiagnosis hipertiroid di RSUP Dr. Kariadi Semarang pada bulan Juni sampai bulan Agustus 2016. Sampel penelitian sejumlah 42 orang yang melakukan pemeriksaan fungsi tiroid dan koagulasi. Kriteria inklusi penelitian ini adalah pasien yang didiagnosis hipertiroid, berusia diatas 18 tahun, wanita dengan menstruasi teratur, hasil pemeriksaan hematologi dalam batas nilai rujukan, gambaran sediaan hapus darah tepi normal, hasil pemeriksaan fungsi hepar dalam batas rujukan sedangkan kriteria eksklusi adalah penderita pasca operasi, mengkonsumsi obat-obatan yang mengganggu koagulasi. Data TSH dan FT4 dideteksi dengan menggunakan metode enzyme linked fluorescence assay. Data PPT dan PTTK diukur dengan menggunakan alat hematologi analyzer.

Data dianalisis dengan menggunakan uji normalitas Saphiro-Wilk test dan didapatkan distribusi data tidak normal yang kemudian disajikan dalam bentuk median. Korelasi TSH, FT4, PPT, dan PTTK dinilai menggunakan Spearman test.

\section{HASIL}

Hasil penelitian terhadap pasien hipertiroid sejak bulan Juni - Agustus 2016 di RSDK didapatkan 42 subjek penelitian yang memenuhi kriteria inklusi dan eksklusi. Karakteristik pasien terdiri dari $73,8 \%$ perempuan dan 26,2\% laki-laki dengan rerata umur 48,24 $\pm 14,2$ tahun. Data karakteristik pasien dapat dilihat pada tabel 1.

Hasil penelitian menunjukkan bahwa kadar TSH tidak mempunyai hubungan terhadap kadar FT4 $(p=0,908 ; \mathrm{r}=-0,018)$. Kadar TSH mempunyai hubungan positif lemah terhadap PPT $(p=0,023 ; \mathrm{r}=0,35)$ dan tidak berhubungan dengan PTTK $(p=0,165 ; \mathrm{r}=0,218)$. Berbeda dengan hasil penelitian Debeij et al yang menyatakan bahwa umumnya kadar FT4 yang dihubungkan dengan

\begin{tabular}{|c|c|c|}
\hline Parameter & Rerata \pm SB & n (\%) \\
\hline Umur (tahun) & $48,24 \pm 14,2$ & \\
\hline \multicolumn{3}{|l|}{ Jenis kelamin } \\
\hline Pria & & $31(73,8)$ \\
\hline Wanita & & $11(26,2)$ \\
\hline \multicolumn{3}{|l|}{$\mathrm{TSH}(\mu \mathrm{IU} / \mathrm{mL})$} \\
\hline \multicolumn{3}{|l|}{ FT4 (pmol/L) } \\
\hline PPT (detik) & & \\
\hline PTTK (detik) & & \\
\hline
\end{tabular}

$\mu \mathrm{IU}$ : micro international unit, $\mathrm{mL}$ : milliliter, pmol: picomol, L: liter, TSH : thyroid stimulating hormone, FT4 : free tetraiodothyronine, PPT : plasma prothrombin time, PTTK : partial thromboplastin time with kaolin 
TABEL 2

Hubungan kadar TSH dan FT4 terhadap nilai PPT dan PTTK pada pasien hipertiroid

\begin{tabular}{lccccccc} 
Variabel & & FT4 & \multicolumn{2}{c}{ FT4 } & \multicolumn{2}{c}{ FT4 } \\
& $\mathbf{r}$ & $\boldsymbol{p}$ & $\mathbf{r}$ & $\boldsymbol{p}$ & $\mathbf{r}$ & $\boldsymbol{p}$ \\
\hline TSH & $-0,018$ & 0,908 & $0,350^{*}$ & 0,023 & 0,218 & 0,165 \\
FT4 & - & - & 0,219 & 0,164 & $-0,111$ & 0,486 \\
\hline
\end{tabular}

*Koefisien korelasi signifikan pada 0,05 (2-tailed)

perubahan parameter koagulasi namun belum diketahui apakah efek tersebut sebagian diantarai oleh TSH. ${ }^{3}$

\section{DISKUSI}

Respon hipofisis TSH tergantung pada besar penyimpangan kadar sirkulasi FT4 dari titik optimumnya dan dapat mengalami perubahan yang kurang kuat atau berlebihan sesuai dengan besarnya deviasi penurunan FT4. ${ }^{6}$ Hong Lidalam penelitiannya menyatakan bahwa tingkat keparahan hipertiroid hanya berkorelasi sebagian dengan serum FT4 dan tidak terdapat korelasi yang kuat antara simptom tiroid dan kadar serum FT4. ${ }^{7}$ Hasil FT4 dapat dipengaruhi oleh banyak faktor, seperti tiroglobulin (TBG), penyakit serius, atau obat-obatan tertentu yang dapat mengganggu ikatan FT4 dengan hormon. ${ }^{7,8}$

Hormon mempengaruhi keseimbangan hemostasis secara langsung. ${ }^{9}$ Penelitian Debeij et al pada pasien dengan kadar FT4 stabil disertai peningkatan kadar TSH menunjukkan tidak adanya pengaruh yang jelas pada parameter koagulasi yang dapat diamati. Pasien dengan kadar TSH tinggi dan kadar FT4 rendah kemudian mengalami perubahan menjadi TSH rendah dan kadar FT4 agak meningkat, terjadi peningkatan yang jelas tampak pada kadar FVIII, FIX, vWF dan fibrinogen. Hal ini telah membuktikan bahwa perubahan kadar parameter koagulasi sebanding dengan peningkatan kadar FT4, bukan karena perubahan kadar TSH. ${ }^{3}$ Penelitian Li Ll et al melaporkan bahwa pasien hipertiroid diketahui mengalami pemendekkan PTTK dan kadar fibrinogen lebih tinggi dibandingkan pada orang dengan fungsi tiroid normal. ${ }^{4}$ Terdapat dua kemungkinan mekanisme bagaimana hormon tiroid berpengaruh pada koagulasi yaitu: pertama, kelebihan atau defisiensi hormon tiroid; dan kedua, penyakit autoimun yang berkaitkan dengan penyakit tiroid. ${ }^{3}$ FT4 kemungkinan mempunyai efek langsung terhadap transkripsi gen pada hepatosit dan sel-sel endothelial yang nantinya menyebabkan peningkatan produksi faktor-faktor koagulasi. ${ }^{10}$ Sampai saat ini belum terdapat teori dan penjelasan tentang mekanisme hormon tiroid mempengaruhi koagulasi. ${ }^{3,10}$

\section{SIMPULAN}

Terdapat hubungan positif lemah antara TSH dan PPT. Tidak terdapat hubungan bermakna antara TSH dan FT4, TSH dan PTTK, dan FT4 terhadap PPT dan PTTK. Dibutuhkan penelitian kohort pada pasien hipertiroid dengan terapi untuk membuktikan apakah hormon tiroid mempunyai hubungan dengan perubahan koagulasi.

\section{DAFTAR PUSTAKA}

1. Giannelli FR. Hyperthyroidism. J American Academy of Physician Assistans, 2015; 28(8): p57-8.

2. Badan Penelitian dan Pengembangan Kesehatan Kementerian Kesehatan RI. Riset Kesehatan Dasar 2013. 2013.

3. Li Ll, et al. Negative association between free triiodothyronine level and international normalized ratio in euthyroid subjects with acute myocardial infarction. Acta Pharmacologica Sinica, 2011;32: 1352-6.

4. Debeij J, et al. The effect of changes in thyroxine and thyroidstimulating hormone levels on the coagulation system. J Thromb Haemost, 2010; 8: 2823-44.

5. Killic N, et al. Procoagulant and anticoagulant factors in childhood hypothyroidism. International Journal of Endocrinology. Volume 2012.

6. Hoermann R, Eckl W, Hoermann C, Larisch R. Complex relationship between free thyroxine and TSH in the regulation of thyroid function. Eur J Endocrinol, 2010; 162: p.1123-29.

7. Li Hong et al. Clinical evaluation of various thyroid hormones on thyroid function. International J Endocrinol, 2014, Article ID 618572, 5 pages, 2014. doi:10.1155/2014/618572.

8. Turgeon ML. Linne \& Ringsrud's Clinical Laboratory Science. $6^{\text {th }}$ ed. Maryland: Elsevier. 2012.p.252-3.

9. Squizzato A, Romualdi E, Büller R, Gerdes V E A. Clinical review: Thyroid disfunction and effects on coagulation and fibrinolysis: A systematic review. J Clin Endocrinol Metab, 2007; 92(7): p.2415-20.

10. Debeij J, et al. Increased levels of free thyroxine and risk of venous thrombosis in a large population-based prospective study. J Thromb Haemost, 2012; 10: p.1539-46. 